\title{
Impact of Network Factors on Supply Chain Performance: A Case of Textile Sector of Pakistan
}

\author{
Nadir Munir Hassan ${ }^{a}$, Muhammad Nauman Abbasi ${ }^{b}$ \\ a Assistant Professor, Department of Business Administration, Air University, Multan, Pakistan \\ Email: nadir.magsi@aumc.edu.pk \\ ${ }^{\mathrm{b}}$ Professor, Institute of Management Sciences, Bahauddin Zakaraiya University, Multan, Pakistan \\ Email: abbasimna@bzu.edu.pk
}

\begin{tabular}{|c|c|}
\hline ARTICLE DETAILS & ABSTRACT \\
\hline History: & \multirow{11}{*}{$\begin{array}{l}\text { This study elaborates the importance of network perspective in driving } \\
\text { performance outcomes especially in the context of agriculture (Textile) } \\
\text { supply chains. The impact of network factors (i.e. actors, resources, and } \\
\text { activities) on overall supply chain performance have been explored. By } \\
\text { deploying survey, a two-stage cluster sampling was used to attain study } \\
\text { objectives. The Textile firms from Punjab and Sindh were selected for } \\
\text { data collection. Through a structured questionnaire, } 482 \text { responses were } \\
\text { generated and analyzed using PLS-SEM. The findings of the study } \\
\text { confirmed that Network Actors (Textile Firms), the activities they } \\
\text { perform, and the resources they have, generate a significant and positive } \\
\text { impact on supply chain performance. The study recommends the need } \\
\text { for understanding the role of integrative initiatives between the studied } \\
\text { variables, i.e. network factors. Further, it is argued that integrated } \\
\text { Network Factors can generate a significant impact on Supply Chain } \\
\text { Performance. }\end{array}$} \\
\hline Accepted 30 July 2021 & \\
\hline Available Online September 2021 & \\
\hline Keywords: & \\
\hline Network perspective, Supply & \\
\hline Chain Performance, Supply Chain & \\
\hline Integration, Agriculture (Textile) & \\
\hline Supply Chain & \\
\hline JEL Classification: & \\
\hline$R 41, L 25, L 29$ & \\
\hline & \\
\hline
\end{tabular}

(C) 2021 The authors. Published by SPCRD Global Publishing. This is an open access article under the Creative Commons AttributionNonCommercial 4.0

Corresponding author's email address: abbasimna@bzu.edu.pk

\section{Introduction}

In the recent era, increasing interest in technological adoption and digitization at large has raised the need for mindful synchronization between firms, and supply chains. Specifically for agrobased industries which are striving to compete in the market for better profits and also significantly contributing to the overall GDP of the country, through increased reach to international markets. In the given era, businesses are heading towards saturated and complex markets, and the competition has moved beyond firms, and now it's between supply chains. The concept of looking onto firms, from the perspective of supply chain management isn't new (Ahmed, Munir, \& Sameer, 2020). Whilst, consistent development and up gradation of theories and new practices reflect that supply chains are increasingly prone to disruption these days.

To tackle the issue of disruption, inconsistencies, and to enhance performance, there is an ever 


\section{Review of Economics and Development Studies, Vol. 7 (3) 2021, 357-370}

rising need for mindfully aligning the chains processes (Khan \& Qianli, 2017). It is believed that better integration across chains can significantly enhance chain performance (Green, McGaughey, \& Casey, 2006; Ho, Au, \& Newton, 2002). For example, Covid-19 has been one such recent environmental phenomenon that has reaffirmed practitioners, researchers and scholars, to look into countering strategies, managing natural and supernatural uncertainties across value chains. This is the era in which there is an ever rising need for thoughtful relationship management within and across the chains. It is need of the hour to realize that, in the given competitive business environment, chains and firms can hardly operate in isolation. Firms should not undermine the significance of integrating across chains, from raw material acquisition to service delivery to end consumers (Farooq \& O'Brien, 2012; Mungan, Yu, \& Sarker, 2010). While seeking collaboration, one needs to be mindful of the fact that experts have started seeing supply chains as a complex network of manufacturing, processing and resource delivery (Aslam \& Amos, 2010; Zhou, Tu, Han, Xu, \& Ye, 2017), who's operation management require network-based optimization. Likewise, the sequence of flow in SCN management deals with the allocation of material, information and processes to achieve multiple objectives (Ke, Huang, \& Gao, 2018; Wang, Hu, \& Zhou, 2017; Zhang et al., 2019).

For the given reason there exists a dire need for firms (among networks) to develop strong relationships to seek appropriate performance outcomes. Accordingly, the study was initiated to "examine the influence of network factors (i.e. Actors, Resources, and Activities) on supply chain performance". The Textile Industry of Pakistan is targeted to verify the phenomenon under investigation due to its significant contribution to GDP and global markets, i.e. total export of the Pakistan textile sector is 9.6 million US dollars and this makes around 8.5 percent of Pakistan's GDP (Bhutto \& Jamal, 2020). In reality, the Textile Supply Chains (TSC) are comparatively complex because of number of reasons including: demand variability, environmental concerns, product variety, lack of product standardization, and seasonality (Majumdar \& Sinha, 2019). Despite many studies have explored the significance of integrated network perspective still studies have failed to provide an executable solution and hence remained inconclusive. Therefore, an attempt has been made to understand the role of network factors and to measure their impact on supply chain performance especially in the context of Textile Supply Chains.

\section{Literature Review}

With constant increase in operational technicalities for organizations, reduced life cycles of products, and ever rising need for upgraded customer service made researchers and managers to focus on supply chain management (Davis, 1993). Since 1990s, supply chain view point have been at the epicenter of firms looking to provide their stakeholders with services, in line with the market trends. Resultantly they have been eyeing managing their operations in line with best supply chain practices (e.g. (Stevens, 1989). SCM has been defined as the set of tools and techniques used for managing supply chain activities for effective coordination to improve overall supply chain performances (Kusi-Sarpong, Sarkis, \& Wang, 2016; Liu, Bai, Liu, \& Wei, 2017).

It's reasoned that efficient management of supply chains depends on; functional attributes, resources at hand, and demand fulfillment (Heckmann, Comes, \& Nickel, 2015). Ideally, all concerning philosophies of SCM consider all supply chain functions for SC strategy formulation, in pursuit of enhancing business performance (Borges \& Vieira, 2014; Muysinaliyev \& Aktamov, 2014). Earlier literature on supply chain still contains contradictory viewpoints, despite number of research initiatives to understand multiple aspects of supply chain, and very scarce performance outcomes of SCM have yet been explored (Bala, 2014; Oualid, Mocan, Dumitrache, \& Amine, 2016). Therefore, number of scholars have propagated the need for detailed insights into the effect of relationship between firms, the 


\section{Review of Economics and Development Studies, Vol. 7 (3) 2021, 357-370}

activities they perform, and the resource they have, on SC performance outcomes.

The significance of SC relations from the viewpoint of the network perspective is not hidden anymore. A network is a system shaped by core factors (e.g. actors, activities and resources) that join the number of linked firms (L. Jraisat, 2016b). A network is defined as a set of links among constellations of actors (Jarillo, 1988; Ritter \& Gemünden, 2004; Sanzo et al., 2003) and these links make connections with each other to provide functions in a two-way process for overall firms' performance. Network perspective helps in providing with a workable framework for evaluating the business dynamics, wherein, firms (as actors) aimed to have better control and resource allocation over vertical supply chains including production, logistics and marketing activities (Mikkola, 20o8). Herein, the management of network relationships can be viewed as a primary driver of both B2B and B2C markets (Grönroos, 2011; C. Harland, Zheng, Johnsen, \& Lamming, 2004; Lazzarini, Chaddad, \& Cook, 2001). Unfortunately, lack of coordination, synchronization and integration among network factors is regarded as one of the vital reason behind deterioration of SC performance.

In networks, actors (firms) connect each other functionally to bring suppliers, producers, logistic providers and consumers together. The key actor creates a position that enhances strategic transaction and firms' performance (Sanzo, Santos, Vázquez, \& Álvarez, 2003) and is being flexible to be oriented by customer preferences (Dalvi \& Kant, 2015). Authors like, (C. M. Harland, 1996b; Mikkola, 2008; Ritter \& Gemünden, 2004) have recommended, business stature (e.g. Investment with partners, firms reputation, and leadership), Social alignment (i.e. Socializing and developing a certain integrative bond with channel members across value chain). Business Position (i.e. leadership position in the industry backed the reputation), Social bonds (e.g. Social activities and friendships with other members of the supply chains), Image (e.g. family name, and recognition intensity of the firm), \& relationship partners (e.g. partners of new products) to illustrate the role of actors in a network perspective.

Similarly, effective resources allocation and utilization, is always considered as a hallmark to attain competitive advantage, hence, wise allocation of resources especially within network perspective leads to remarkable gains within and across the chain (Mikkola, 2008). The extent to which resources are shared notably influence the performance of the firm and their chain members (Christensen \& Klyver, 2006). Literature suggests four classifications of resource that includes; Physical resources (e.g. facilities that have the ability to assist the flow of information, both within and across the organizations), financial resources (e.g. staff related assistance, and other facilitations) and informational resources (i.e. information sharing both inside and beyond firms among channel members) (Ritter, 1999).

Similarly, SC activities play their part in converting resources into meaningful form, in order to encourage actors to attain their objectives and fortify the interconnectivity within the supply chain networks. Moreover, activities have an important role in improving coordination, cooperation \& collaboration between actors (Bourlakis \& Bourlakis, 2005). SC activities majorly include; exchange activities (i.e. flow of information, products, personnel and money), planning activities (i.e. analyzing the internal networks and thinking over the future course of action), organizing activities (e.g. assembling and allocating the available resources) and controlling activities (i.e. checking mechanisms through staff management and information exchange) (Ritter, 1999). This is where networks create various exchanges to reach out the required resources and through mindful leadership, access to prompt information, which could help in making the right decisions for improved businesses and SC performance. 


\section{Review of Economics and Development Studies, Vol. 7 (3) 2021, 357-370}

Interestingly, SC performance is a multidimensional construct, hence, measured differently by different authors. For example, Maestrini et a. (2018) stated it as "a set of metrics used to quantify both the efficiency and effectiveness of actions." While, Nugraha and Hakimah (2019) studied SC performance in the context of supplier partnership, customer relationship, information sharing, and technology adoption. Sudusinghe and Seuring (2020) (for textile \& apparel supply chains) have measured SC performance considering social and economic sustainability as performance parameters. Resultantly, high performing supply chains usually depend on their cutting edge abilities of their channel members, and on their endeavors to establish relationships across supply chain networks (Michalski, Montes-Botella, \& Narasimhan, 2018).

In line with the stated discussion, the given hypotheses have been formulated for empirical verification;

$H_{1}$ : Network actors (SC firms) have a significant impact on SC performance.

$\mathrm{H}_{2}$ : Network resources have a significant impact on SC performance.

$\mathrm{H}_{3}$ : Network activities have a significant impact on SC performance.

\section{Research Methodology}

A structured questionnaire was used to test the hypotheses. While, a partial least squares structural equation modeling (PLS-SEM), widely recommended for management research (Kaufmann \& Gaeckler, 2015), was applied to investigate and testify the phenomenon under investigation. Grounded in the literature, a framework has been established to investigate the direct relationship between network factors (i.e. Network Actors, Resources, and Activities) and SC performance. The theoretical framework comprises of one broader IV (i.e. Network Perspective), divided into three aspects (i.e. Network Factor), termed as AC, RS, \& AV, while, SC performance (SCP) is observed as DV. Smart PLS 3 Ringle, Da Silva, and Bido (2015) along with bootstrapping technique were utilities to observe the significance level of assumed relationships. Initially, framework was used to gather firstorder constructs, followed by estimation of structural model, and second-order constructs estimation (Joseph F Hair, Risher, Sarstedt, \& Ringle, 2019).

\subsection{Population and Sampling Technique:}

The Textile Sector of Pakistan was selected for data collection and empirical verification of the phenomenon under investigation due to its economic significance. Unfortunately, the Textile sector is stagnant for a long, when related industries in neighboring countries like, India, and Bangladesh have shown reasonable growth. This increases the need to probe the factors that hinder SC performance in this sector. Literature also emphasizes on increasing attention towards the implementation of integrational strategies which can greatly influence SC performance and can enhance the competitiveness in Textile supply chains (Verma et al., 2020).

The target population was comprised of Textile Units. Official representative authorities/bodies, i.e. All Pakistan Textile Mills Association (APTMA) and All Pakistan Bedsheets and Upholstery Manufacturers Association (APBUMA) were requested to provide a list(s) of Textile Units operating in these regions. The list(s) includes 1776, registered Textile Units, involved in spinning, weaving, processing (knitting), dyeing, printing, garment manufacturing and filament yarn manufacturing. The listed firms were divided into four geographical clusters (i.e. Punjab, Sindh, Baluchistan and Khyber Pakhtunkhwa). Furthermore, using multi-stage, cluster probability sampling was applied to consider only 'Registered Textile Units' operating in Punjab (i.e. largest cotton producer) and Sindh (i.e. seaport for export purposes). 
Review of Economics and Development Studies, Vol. 7 (3) 2021, 357-370

Table 1:- Cluster sampling with proportionate technique

\begin{tabular}{|c|c|c|c|c|c|c|c|c|}
\hline $\begin{array}{l}\text { Details } \\
\text { into } \\
\text { Clusters }\end{array}$ & $\begin{array}{l}\text { Firms } \\
\text { in } \\
\text { Cities }\end{array}$ & $\begin{array}{l}\text { Total } \\
\text { Textile } \\
\text { Firms }\end{array}$ & $\begin{array}{l}\text { Rule of } \\
\text { Thumb } \\
\text { (Multiply } \\
\text { by 5/ } 10 \\
\text { Max) }\end{array}$ & $\begin{array}{l}\text { Sample } \\
\text { Size } \\
\text { Req. } \\
\text { Morgan } \\
\text { Table } \\
\text { Error: } \\
5 \%\end{array}$ & $\begin{array}{l}\text { Req. } \\
\text { Sample } \\
\text { from } \\
\text { Each } \\
\text { Cluster } \\
\text { (city } \\
\text { wise) }\end{array}$ & $\begin{array}{l}\text { Questionnaire } \\
\text { Distributed } \\
\text { (Organization } \\
\text { wise) } \\
\text { Total= } 726\end{array}$ & $\begin{array}{l}\text { Response } \\
\text { Received } \\
\text { (Organization } \\
\text { wise) } \\
\text { Total= } 493\end{array}$ & $\begin{array}{l}\text { City wise } \\
\text { Response } \\
\text { Rate (in } \\
\text { \%age) } \\
\text { Overall } \\
\text { response= } \\
68 \%\end{array}$ \\
\hline \multicolumn{9}{|l|}{ Punjab } \\
\hline Multan & 228 & 1776 & $\begin{array}{l}200 / \\
390\end{array}$ & 322 & 50 & 97 & 64 & 66 \\
\hline Lahore & 384 & 1776 & $\begin{array}{l}200 / \\
390\end{array}$ & 322 & 84 & 146 & 104 & 71 \\
\hline Faisalabad & 443 & 1776 & $\begin{array}{l}200 / \\
390\end{array}$ & 322 & 97 & 178 & 136 & 76 \\
\hline \multicolumn{9}{|l|}{ Sindh } \\
\hline Karachi & 431 & 1776 & $\begin{array}{l}200 / \\
390\end{array}$ & 322 & 94 & 197 & 116 & 59 \\
\hline Others & 290 & 1776 & $\begin{array}{l}200 / \\
390\end{array}$ & 322 & 64 & 108 & 73 & 68 \\
\hline
\end{tabular}

Managers representing Marketing, Operations and Production and Supply Chain departments were selected as a respondent. Practically, bigger sample size is preferable to avoid non-response bias (Sekaran \& Bougie, 2003). However, due to the prevailing pandemic (Covid-19), data collection remained quite challenging, yet it produced good output with a useable response of 482 (i.e. $68 \%$ ), out of 726 distributed questionnaires. The demographic details are presented in Table-2: 
Review of Economics and Development Studies, Vol. 7 (3) 2021, 357-370

Table 2:- Demographic specifications of the Respondents

\begin{tabular}{|c|c|c|c|}
\hline DEMOGRAPHICS & DESCRIPTION & RESPONSE RATE & $\begin{array}{c}\% \text { OF } \\
\text { RESPONSES }\end{array}$ \\
\hline \multirow{2}{*}{ Gender } & Male & 408 & 84.64 \\
\hline & Female & 74 & $15 \cdot 35$ \\
\hline \multirow{5}{*}{ Age } & Less Than 3oYrs & 64 & 13.27 \\
\hline & 30-4oyrs & 298 & 61.82 \\
\hline & 41-50yrs & 84 & 17.42 \\
\hline & $51-60 y r s$ & 36 & $7 \cdot 49$ \\
\hline & Above 61yrs & $\mathrm{O}$ & \\
\hline \multirow{3}{*}{ Qualification } & College Level & 4 & 0.8 \\
\hline & Under Graduate & 326 & 67.63 \\
\hline & Post Graduate & 152 & 31.57 \\
\hline \multirow{3}{*}{ Position } & $\begin{array}{l}\text { Top Management / Director / CFO / } \\
\text { Company Secretary }\end{array}$ & 62 & 12.86 \\
\hline & General Manager / Sr. Manager & 214 & $44 \cdot 39$ \\
\hline & Production In charge / Mill Manager & 206 & 42.75 \\
\hline \multirow{5}{*}{ Operational Sector } & Spinning & 221 & 44.60 \\
\hline & Weaving & 121 & 25.10 \\
\hline & Knitting & 27 & 5.5 \\
\hline & Dyeing and Finishing & 84 & 16.42 \\
\hline & Garments & 40 & 8.38 \\
\hline \multirow{5}{*}{ Company Location } & Multan & 77 & 16 \\
\hline & Lahore & 1070 & 22 \\
\hline & Faisalabad & 123 & 25 \\
\hline & Karachi & 131 & 27 \\
\hline & Others & 44 & 10 \\
\hline
\end{tabular}

\subsection{Operationalization of the Measurement Instruments}

To measure 'Network Actors', 4-Items scale suggested by C. M. Harland, (1996b); L. Jraisat, (2016b); Mikkola, (2008); Ritter \& Gemünden, (2004), while, for 'Network Resources' 4-Items scale by L. Jraisat, (2016b) and Ritter, (1999) have been adopted. Similarly, 4-items scale as suggested by L. Jraisat, (2016b); Ritter, (1999); Ritter \& Gemünden, (2004) were adapted to measure the construct of 'Network Activities'. Finally, 11-Item scale of SC performance has been adopted from (Green Jr, Whitten, \& Inman, 2008). The responses were measured on Likert scale, ranging from 1 to 7, wherein, 1 stands for strongly disagree and 7 stand for strongly agree. 
Review of Economics and Development Studies, Vol. 7 (3) 2021, 357-370

Table 3:- Variables, Items \& Cronbach Alpha

\begin{tabular}{|c|c|c|}
\hline VARIABLES & NUMBER OF ITEMS & $\begin{array}{l}\text { CRONBACH } \\
\text { ALPHA }\end{array}$ \\
\hline \multirow{4}{*}{ Network Actors } & My firm has a good image and a leadership position. & \multirow{3}{*}{0.785} \\
\hline & $\begin{array}{l}\text { My firm keeps doing of social events and friendships with other } \\
\text { actors. }\end{array}$ & \\
\hline & $\begin{array}{l}\text { My firm is considered as a pioneer and family business recognized } \\
\text { in the chain. }\end{array}$ & \\
\hline & My firm creates relationships with new actors. & \\
\hline \multirow{4}{*}{$\begin{array}{l}\text { Network } \\
\text { Resources }\end{array}$} & $\begin{array}{l}\text { My firm offers information exchange inside the firm and between } \\
\text { firms. }\end{array}$ & \multirow{4}{*}{0.719} \\
\hline & $\begin{array}{l}\text { My firm's top management has financial support offered for staff } \\
\text { and new development. }\end{array}$ & \\
\hline & My firm's staff are trained by local and/or international experts. & \\
\hline & $\begin{array}{l}\text { My firm provides infrastructures for harvesting and post- } \\
\text { harvesting. }\end{array}$ & \\
\hline \multirow{4}{*}{$\begin{array}{l}\text { Network } \\
\text { Activities }\end{array}$} & $\begin{array}{l}\text { There are exchanges of goods, services, money, information and } \\
\text { personnel between my firm \& its partners. }\end{array}$ & \multirow{4}{*}{0.747} \\
\hline & $\begin{array}{l}\text { There are analyses of network quality and resources and network } \\
\text { environment by my firm. }\end{array}$ & \\
\hline & $\begin{array}{l}\text { There are formal and/or informal agreements between my firm \& } \\
\text { its partners. }\end{array}$ & \\
\hline & There are controls of the network output by my firm. & \\
\hline \multirow{11}{*}{$\begin{array}{c}\text { SC } \\
\text { Performance }\end{array}$} & $\begin{array}{l}\text { My firm's primary Supply chain has the ability to deliver Zero- } \\
\text { Defect products to final customers. }\end{array}$ & \multirow{11}{*}{0.881} \\
\hline & $\begin{array}{l}\text { My firm's primary Supply chain has the ability to deliver value } \\
\text { added services to end customers. }\end{array}$ & \\
\hline & $\begin{array}{l}\text { My firm's primary Supply chain has the ability to eliminate late, } \\
\text { damaged, and incomplete orders to final customers. }\end{array}$ & \\
\hline & $\begin{array}{l}\text { My firms primary Supply chain has the ability to quickly respond, } \\
\text { to and solve problems, of final customers. }\end{array}$ & \\
\hline & $\begin{array}{l}\text { My firm's primary Supply chain has the ability to deliver products } \\
\text { precisely on time to final customers. }\end{array}$ & \\
\hline & $\begin{array}{l}\text { My firm's primary Supply chain has the ability to deliver precise } \\
\text { quantities to final customers. }\end{array}$ & \\
\hline & $\begin{array}{l}\text { My firm's primary Supply chain has the ability to deliver shipment } \\
\text { of variable size on frequent basis to final customers. }\end{array}$ & \\
\hline & $\begin{array}{l}\text { My firm's primary Supply chain has the ability to minimize total } \\
\text { product cost to final customers. }\end{array}$ & \\
\hline & $\begin{array}{l}\text { My firm's primary Supply chain has the ability to minimize all } \\
\text { types of waste throughout the supply chain. }\end{array}$ & \\
\hline & $\begin{array}{l}\text { My firms primary Supply chain has the ability to channel safety } \\
\text { stock throughout the supply chain }\end{array}$ & \\
\hline & $\begin{array}{l}\text { My firms primary Supply chain has the ability to deliver smaller lot } \\
\text { sizes and shipping case sizes to final customers }\end{array}$ & \\
\hline
\end{tabular}




\section{Results}

Considering the significance of common method bias in data (Bagozzi, 2011), the current study used (un-rotated) factor analysis with 23 items of the constructs, reflected that none of the factors accounted for more than $50 \%$ of the variance. Output revealed $36 \%$ of total variance accounted by a single factor that reflects the absence of common method bias. Furthermore, in order to check the reliability and suitability of the data used, data screening was managed. Based on the recommendations of Joseph et al (2010), out of 493 responses, 11 responses were deemed invalid and hence eliminated. The descriptive scores (mean value) remained in between 5.52 to 6.36 and (standard deviation) 1.08 to 1.79.

Structural models were looked into after ensuring the reliability and validity of the variables under consideration, followed by measuring the relationships between latent variables. Smart PLS 3.0 by Ringle et al., (2015) was used to determine causal links among the constructs in these theoretical models, and to evaluate the outer model (measurement model) and the inner model (structural model). This study adopts a two-step process; one is an assessment of measurement model and second one measurement of structural model (Joseph F Hair, Ringle, \& Sarstedt, 2013; Hair Jr et al., 2014). Further, Confirmatory Factor Analysis (CFA) was employed and out of 23 items, o6 were deleted with loadings lesser than the cutoff value of 0.50 . All variables have AVE and composite reliability above the threshold value of 0.50 (Fornell \& Larcker, 1981; Hair Jr et al., 2014), while, the values of Cronbach's Alpha (above then threshold level, i.e. o.7) reflects internal consistency. The discriminant validity was analyzed by using AVE as recommended by (Fornell \& Larcker, 1981). The comparison among the latent constructs as explained in Table 4 \& 5 summarize the square root of AVE of the constructs; i.e. Network Actors $(\mathrm{AC})=0.821$; Network Resources $(\mathrm{RS})=0.799$; Network Activities $(\mathrm{AV})=0.813$; and SC Performance $(\mathrm{SCP})=0.74$.

Table 4:- Loadings, Composite Reliability and AVE

\begin{tabular}{|c|c|c|c|c|c|}
\hline CONSTRUCTS & ITEMS & $\begin{array}{c}\text { OUTER } \\
\text { LOADINGS }\end{array}$ & VIF & $\begin{array}{l}\text { COMPOSITE } \\
\text { RELIABILITY }\end{array}$ & $\begin{array}{c}\text { AVERAGE } \\
\text { VARIANCE } \\
\text { EXTRACTED (AVE) }\end{array}$ \\
\hline \multirow{3}{*}{ Network Actor } & AR1 & 0.774 & 1.288 & \multirow{3}{*}{0.861} & \multirow{3}{*}{0.674} \\
\hline & $\mathrm{AR}_{3}$ & 0.853 & 1.921 & & \\
\hline & $\mathrm{AR}_{4}$ & 0.834 & 1.873 & & \\
\hline \multirow{3}{*}{$\begin{array}{l}\text { Network } \\
\text { Activities }\end{array}$} & $\mathrm{AV} 1$ & 0.801 & 1.358 & \multirow{3}{*}{0.854} & \multirow{3}{*}{0.661} \\
\hline & $\mathrm{AV} 2$ & 0.787 & 1.602 & & \\
\hline & $\mathrm{AV}_{3}$ & 0.849 & 1.617 & & \\
\hline \multirow{3}{*}{$\begin{array}{l}\text { Network } \\
\text { Resource }\end{array}$} & $\mathrm{RS} 1$ & 0.787 & 1.408 & \multirow{3}{*}{0.841} & \multirow{3}{*}{0.638} \\
\hline & $\mathrm{RS} 2$ & 0.774 & 1.396 & & \\
\hline & RS3 & 0.834 & 1.419 & & \\
\hline \multirow{8}{*}{ SC Performance } & SCP1 & 0.674 & 1.774 & \multirow{8}{*}{0.906} & \multirow{8}{*}{0.548} \\
\hline & $\mathrm{SCP} 2$ & 0.694 & 1.991 & & \\
\hline & $\mathrm{SCP}_{3}$ & 0.718 & 1.752 & & \\
\hline & $\mathrm{SCP}_{4}$ & 0.827 & 2.69 & & \\
\hline & $\mathrm{SCP}_{5}$ & 0.749 & 2.446 & & \\
\hline & SCP6 & 0.824 & 2.877 & & \\
\hline & $\mathrm{SCP} 7$ & 0.741 & 2.179 & & \\
\hline & SCP8 & 0.678 & 1.672 & & \\
\hline
\end{tabular}


Review of Economics and Development Studies, Vol. 7 (3) 2021, 357-370

Table 5:- Discriminant Validity Matric

\begin{tabular}{|l|c|l|l|l|}
\hline \multicolumn{1}{|l|}{ FORNEL LARCKER CRITERION } & $\begin{array}{l}\text { Network } \\
\text { Activities }\end{array}$ & $\begin{array}{l}\text { Network } \\
\text { Actor }\end{array}$ & $\begin{array}{l}\text { Network } \\
\text { Resource }\end{array}$ & SC Performance \\
\hline Network Activities & $\mathbf{0 . 8 1 3}$ & & & \\
\hline Network Actor & 0.576 & $\mathbf{0 . 8 2 1}$ & & \\
\hline Network Resource & 0.56 & 0.562 & $\mathbf{0 . 7 9 9}$ & \\
\hline SC Performance & 0.598 & 0.641 & 0.67 & $\mathbf{0 . 7 4}$ \\
\hline
\end{tabular}

The measurement model of the given study is as follows:

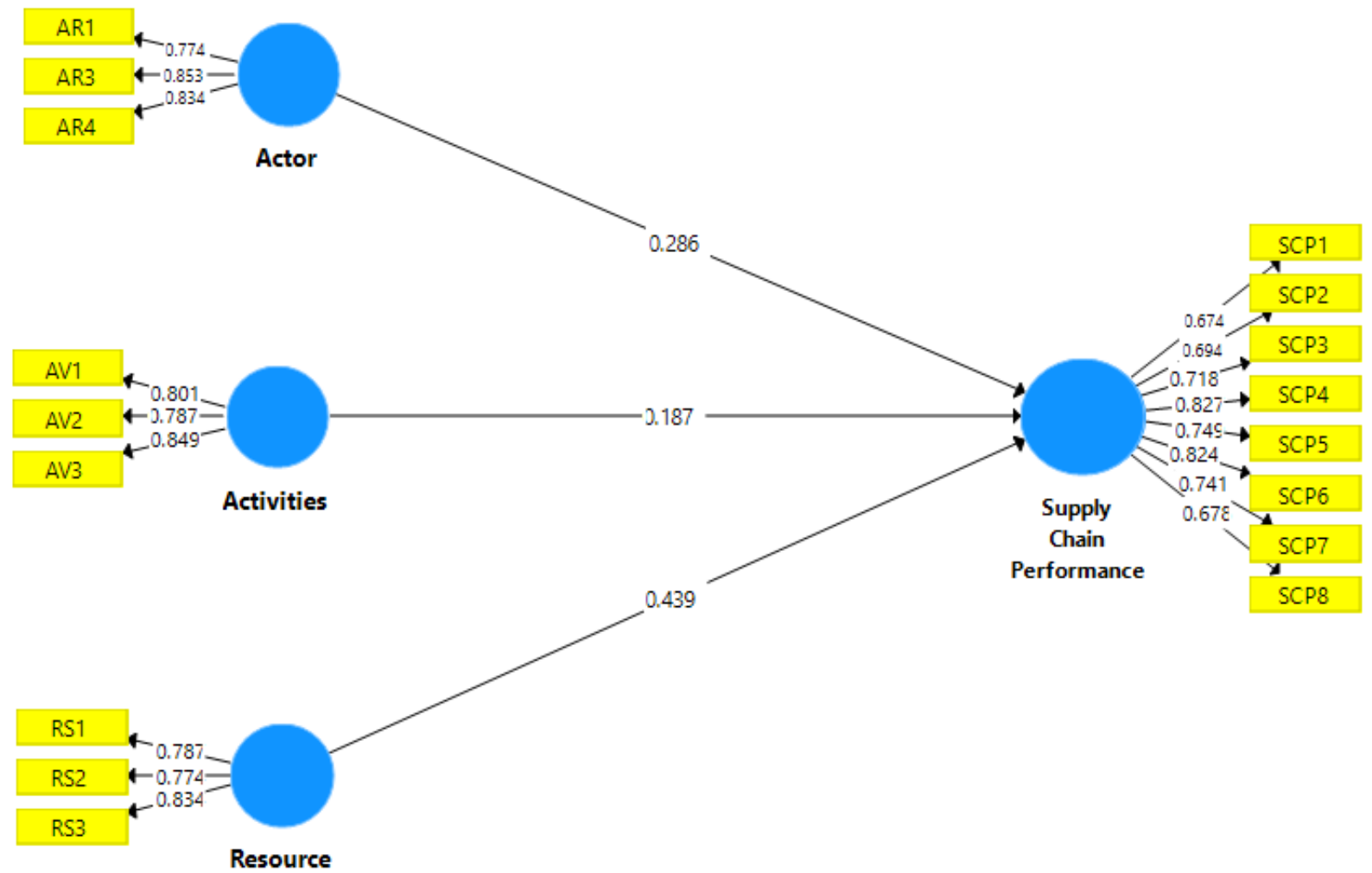

Figure 1:- Measurement Model

\subsection{Assessment of Significance of the Structural Model Direct Relationships}

This section elaborates both the structural (inner model) \& measurement models (outer model), and direct relationships as emphasized by (Joseph F Hair et al., 2010). By making use of the criteria suggested by Hair Jr et al. (2014), the $\mathrm{t}$ - value greater than 1.64 is considered to be as significant, which helps in upcoming decisions concerning the formulated hypothesis. Based on recommended t-value, all of the (03) direct hypothesis, were accepted. The structural model for the given direct relationships are as follows: 


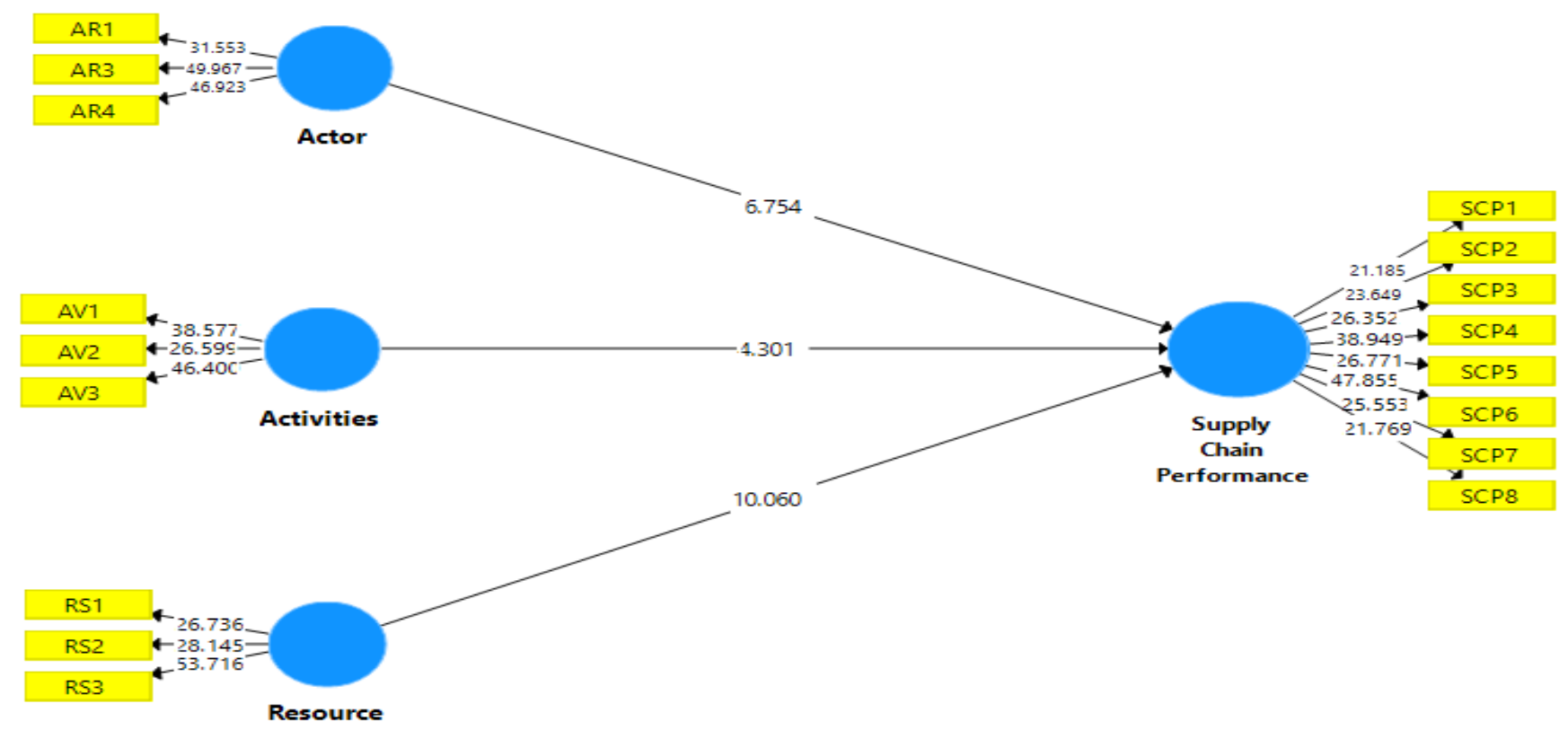

\section{Figure 2:- Structural Model Direct Relationships}

The results presented in Figure 2, generated with the help of Smart-PLS 3.2.8 (Ringle et al., 2015), illustrate the path p-value, t-value, coefficient value and the standard errors. Based on these standard values the hypothesis decision has been made regarding significance level of each hypothesis. While, Table 6 indicates that those hypothesis which were supported in this current research have a pvalue of less than 0.05 .

Table 6:- Hypothesis Testing

\begin{tabular}{|l|c|c|c|c|c|}
\hline DIRECT HYPOTHESIS & BETA & $\begin{array}{c}\text { STANDARD } \\
\text { DEVIATION }\end{array}$ & T STATISTICS & $\begin{array}{c}\text { P } \\
\text { VALUES }\end{array}$ & DECISION \\
\hline Activities -> SC Performance & 0.187 & 0.044 & 4.301 & 0.000 & Supported \\
\hline Actors -> SC Performance & 0.286 & 0.042 & 6.754 & 0.000 & Supported \\
\hline $\begin{array}{l}\text { Resources - > SC } \\
\text { Performance }\end{array}$ & 0.439 & 0.044 & 10.060 & 0.000 & Supported \\
\hline
\end{tabular}

\section{Discussions}

The outcomes of this study, empirically verify the impact of network perspective (i.e. actors, resources, and activities), on SC performance. Though, the outcomes are contextual and was specifically tested for Textile Supply Chains, still it adds newness and valuable insights to the existing body of knowledge. By considering, multi-factors network factors, fundamental question like, why firms, when aligning their resources and activities with channel partners (as a network) can help in enhancing SC performance in developing nations, such as Pakistan.

However, the topic pursued for empirical outcomes is just a beginning in understanding the use of network perspective in TSC. Empirical outcomes have reflected a positive significant relationship between all three network factors (i.e. actors, resources, and activities) on SC performance. It supports 


\section{Review of Economics and Development Studies, Vol. 7 (3) 2021, 357-370}

the idea of channel members across agriculture (textile) chains exchanging, sharing, and coordinating their resources and activities with each other. The results authenticate that channel members need to come closer to each other and to strengthen their relations for better SC performance. The outcomes of the given study, conjoin with the outcomes and suggestions of the previous research studies, propagating a positive relationship between network factors and business performance outcomes (Håkansson, Havila, \& Pedersen, 1999; C. M. Harland, 1996b; Kahiya \& Dean, 2014; Mikkola, 2008).

It is important to note that practically, actors across Textile Supply Chains are subject to number of procedural and bureaucratic contingencies, which hinder their smooth alignments across value chains. Similarly, SC activities across agriculture (Textile) chains are mostly managed at an individual level, but if managed in a coordinated manner across firms and chains, will help in managing the issues of both shortages and surplus of output produced. Lastly, resources aren't shared as such across chains, which causes the compromised performance outcomes. So, if resources will also be aligned across channel members will takes the burden off from all textile units, and compromised ones in particular and help them in contributing towards overall supply chain performance.

Practically, the study brings to fore, some of the future research related questions. Future studies can look into the possibilities of, how to integrate network factors in a better planned manner, for achieving the overall SC performance (Duffy, 2008; Dyer \& Nobeoka, 2000; Le, Thi Nguyen, \& Van Nguyen, 2013). Researchers can also pursue the longitudinal research approach, to develop a better idea on how, integration among network factors across industries takes place, and also on how it helps achieving the overall SC performance. Furthermore, there has been a recent uprising on, use of multiple extent of supply chain integration across value chains, because of varying needs of industries. Future researchers can check the relationship between multiple extents of SCI along network factors, in generating overall chains performance. Future studies can also introduce certain mediating (i.e. supply chain integration dimensions) and moderating variables (i.e. environmental complexity, environmental dynamism \& environmental uncertainty etc.) in through the prism of interpretive lenses like Resource Based View, A-R-A model, and Contingency Theory to address the issues of multiple extents of integration, and contextual nature of value chains networks, across the globe. Likewise, all industries are contextual in nature, and are usually subject to specific uncertainties, the role of moderating variables (e.g. environmental uncertainty, environmental dynamism, \& role of culture etc.) can help researchers in developing a better understanding on how supply chains are better managed (Wiengarten, Li, Singh, \& Fynes, 2019).

Lastly, the given study has implications for firms operating within agriculture (textile) sector of Pakistan and beyond. By considering chains as networks of actors, their resources and activities, firms can take a step towards improving the overall performance. Proper consideration in policy making on network orientation both at dyadic and chain level will be of great utility. It is believed that outcomes of this study, once implemented in true letter and spirit, will also help other industries and manufacturing sectors of Pakistan to enhance their SC performance. Keeping prevailing pandemic (Covid-19) and geostrategic dynamics in mind, it will help Pakistan to increase its textile exports, which eventually will takes the nation in achieving its larger goals of import substitution, ultimately enhancing firms, supply chain and national level performance. 


\section{References}

Ahmed, R., Munir, R., \& Sameer, M. (2020). Impact of supply chain integration on firm performance: Evidence from manufacturing sector of Pakistan. International Journal of Management, 11(08).

Aslam, T., \& Amos, H. N. (2010). Multi-objective optimization for supply chain management: A literature review and new development. Paper presented at the 2010 8th International Conference on Supply Chain Management and Information.

Bala, K. (2014). Supply chain management: Some issues and challenges-A Review. International Journal of Current Engineering and Technology, 4(2), 946-953.

Bhutto, S. A., \& Jamal, Y. (2020).The mediating role of absorptive capacity in the relationship between the dimensions of human capital and organizational performance: A conceptual framework for the textile sector of Pakistan. Reviews of Management Sciences, 2(1).

Borges, M. A. V., \& Vieira, L. M. (2014). Brazil moving up in the Semiconductor Global Chain. Journal of Operations and Supply Chain Management, 7(1), 68-84.

Bourlakis, C., \& Bourlakis, M. (2005). Information technology safeguards, logistics asset specificity and fourth-party logistics network creation in the food retail chain. Journal of Business \& Industrial Marketing.

Christensen, P. R., \& Klyver, K. (2006). Management consultancy in small firms: How does interaction work?. Journal of Small Business and Enterprise Development.

Dalvi, M. V., \& Kant, R. (2015). Benefits, criteria and activities of supplier development: A categorical literature review. Asia Pacific Journal of Marketing and Logistics.

Davis, T. (1993). Effective Supply Chain Management, Sloan Mgmt: Rev.

Duffy, R. S. (2008). Towards a better understanding of partnership attributes: An exploratory analysis of relationship type classification. Industrial Marketing Management, 37(2), 228244. doi:10.1016/j.indmarman.2007.09.005

Dyer, J. H., \& Nobeoka, K. (2000). Creating and managing a high-performance knowledge-sharing network: The Toyota case. Strategic management journal, 21(3), 345-367.

Farooq, S., \& O’Brien, C. (2012). A technology selection framework for integrating manufacturing within a supply chain. International Journal of Production Research, 50(11), 2987-3010.

Fornell, C., \& Larcker, D. F. (1981). Structural equation models with unobservable variables and measurement error: Algebra and statistics. Journal of marketing research, 382-388.

Green Jr, K. W., Whitten, D., \& Inman, R. A. (2008). The impact of aligning marketing strategies throughout the supply chain. Sam Houston State University, Huntsville, TX.

Green, K. W., McGaughey, R., \& Casey, K. M. (2006). Does supply chain management strategy mediate the association between market orientation and organizational performance? Supply Chain Management: An International Journal.

Grönroos, C. (2011). A service perspective on business relationships: The value creation, interaction and marketing interface. Industrial Marketing Management, 40(2), 240-247.

Hair, J. F., Risher, J. J., Sarstedt, M., \& Ringle, C. M. (2019). When to use and how to report the results of PLS-SEM. European Business Review.

Hair, J. F., Celsi, M., Ortinau, D. J., \& Bush, R. P. (2010). Essentials of marketing research (Vol. 2): McGraw-Hill/Irwin New York, NY.

Hair Jr, J. F., Sarstedt, M., Hopkins, L., \& Kuppelwieser, V. G. (2014). Partial least squares structural equation modeling (PLS-SEM). European Business Review.

Håkansson, H., Havila, V., \& Pedersen, A.-C. (1999). Learning in networks. Industrial Marketing Management, 28(5), 443-452.

Harland, C., Zheng, J., Johnsen, T., \& Lamming, R. (2004). A conceptual model for researching the 


\section{Review of Economics and Development Studies, Vol. 7 (3) 2021, 357-370}

creation and operation of supply networks. British Journal of management, 15(1), 1-21.

Harland, C. M. (1996a). Supply chain management: relationships, chains and networks. British Journal of management, 7, S63-S80.

Harland, C. M. (1996b). Supply chain management: relationships, chains and networks. British Journal of management, $7(\mathrm{~s} 1)$.

Heckmann, I., Comes, T., \& Nickel, S. (2015). A critical review on supply chain risk: Definition, measure and modeling. Omega, 52, 119-132.

Ho, D. C., Au, K., \& Newton, E. (2002). Empirical research on supply chain management: A critical review and recommendations. International Journal of Production Research, 40(17), 44154430.

Jarillo, J. C. (1988). On strategic networks. Strategic management journal, 9(1), 31-41.

Jraisat, L. (2016b). A network perspective and value added tasks: the case of agri-food value chain. Asia Pacific Journal of Marketing and Logistics, 28(2), 350-365.

Kahiya, E. T., \& Dean, D. L. (2014). Export performance: multiple predictors and multiple measures approach. Asia Pacific Journal of Marketing and Logistics.

Ke, H., Huang, H., \& Gao, X. (2018). Pricing decision problem in dual-channel supply chain based on experts' belief degrees. Soft Computing, 22(17), 5683-5698.

Khan, S. A. R., \& Qianli, D. (2017). Impact of green supply chain management practices on firms' performance: An empirical study from the perspective of Pakistan. Environmental Science and Pollution Research, 24(20), 16829-16844.

Kusi-Sarpong, S., Sarkis, J., \& Wang, X. (2016). Assessing green supply chain practices in the Ghanaian mining industry: A framework and evaluation. International Journal of Production Economics, 181, 325-341.

Lazzarini, S., Chaddad, F., \& Cook, M. (2001). Integrating supply chain and network analyses: The study of netchains. Journal on chain and network science, 1(1), 7-22.

Le, N.-H., Thi Nguyen, H.-M., \& Van Nguyen, T. (2013). National identity and the perceived values of foreign products with local brands: The case of local wine in Vietnam. Asia Pacific Journal of Marketing and Logistics, 25(5), 765-783.

Liu, W., Bai, E., Liu, L., \& Wei, W. (2017). A framework of sustainable service supply chain management: A literature review and research agenda. Sustainability, 9(3), 421.

Maestrini, V., Luzzini, D., Caniato, F., Maccarrone, P., \& Ronchi, S. (2018). Measuring supply chain performance: a lifecycle framework and a case study. International Journal of Operations \& Production Management.

Majumdar, A., \& Sinha, S. K. (2019). Analyzing the barriers of green textile supply chain management in Southeast Asia using interpretive structural modeling. Sustainable Production and Consumption, 17, 176-187.

Michalski, M., Montes-Botella, J.-L., \& Narasimhan, R. (2018). The impact of asymmetry on performance in different collaboration and integration environments in supply chain management. Supply Chain Management: An International Journal.

Mikkola, M. (2008). Coordinative structures and development of food supply chains. British Food Journal, 110(2), 189-205. doi:10.1108/00070700810849907

Mungan, D., Yu, J., \& Sarker, B. R. (2010). Manufacturing lot-sizing, procurement and delivery schedules over a finite planning horizon. International Journal of Production Research, 48(12), 3619-3636.

Muysinaliyev, A., \& Aktamov, S. (2014). Supply chain management concepts: A literature review. IOSR Journal of Business and Management (IOSR-JBM), 15(6), 6o-66.

Nugraha, A. T., \& Hakimah, Y. (2019). Role of relational capabilities on the supply chain performance of Indonesian textile sector with moderating effect of technology adoption. 
International Journal of Supply Chain Management, 8(5), 509-522.

Oualid, K., Mocan, M. L., Dumitrache, C., \& Amine, G. (2016). Overview of information technology and a theroretical model in supply chain management or local SME's. SEA: Practical Application of Science, 4(3).

Ringle, C., Da Silva, D., \& Bido, D. (2015). Structural equation modeling with the SmartPLS. Bido, D., da Silva, D., \& Ringle, C.(2014). Structural Equation Modeling with the Smartpls. Brazilian Journal Of Marketing, 13(2).

Ritter, T. (1999). The networking company: Antecedents for coping with relationships and networks effectively. Industrial Marketing Management, 28(5), 467-479.

Ritter, T., \& Gemünden, H. G. (2004). The impact of a company's business strategy on its technological competence, network competence and innovation success. Journal of Business Research, 57(5), 548-556.

Sanzo, M. J., Santos, M. L., Vázquez, R., \& Álvarez, L. I. (2003). The role of market orientation in business dyadic relationships: Testing an integrator model. Journal of Marketing Management, 19(1-2), 73-107.

Sekaran, U., \& Bougie, R. (2003). Research Methods For Business, A Skill Building Approach, John Willey \& Sons. Inc. New York.

Stevens, G. C. (1989). Integrating the supply chain. International Journal of Physical Distribution \& Materials Management, 19(8), 3-8.

Sudusinghe, J. I., \& Seuring, S. (2020). Social sustainability empowering the economic sustainability in the global apparel supply chain. Sustainability, 12(7), 2595.

Verma, P., Kumar, V., Jha, A., Muthukumaar, V., Do, M. H., Sharma, N. K., \& Gupta, S. (2020). The degree of collaboration between business units in diversified corporation: A strategic perspective. Business Strategy \& Development, 3(4), 449-46o.

Wang, Z., Hu, H., \& Zhou, W. (2017). RFID Enabled Knowledge-Based Precast Construction Supply Chain. Computer-Aided Civil and Infrastructure Engineering, 32(6), 499-514.

Wiengarten, F., Li, H., Singh, P. J., \& Fynes, B. (2019). Re-evaluating supply chain integration and firm performance: Linking operations strategy to supply chain strategy. Supply Chain Management: An International Journal.

Zhang, X., Du, K.-J., Zhan, Z.-H., Kwong, S., Gu, T.-L., \& Zhang, J. (2019). Cooperative coevolutionary bare-bones particle swarm optimization with function independent decomposition for large-scale supply chain network design with uncertainties. IEEE transactions on cybernetics, 50(10), 4454-4468.

Zhou, X., Tu, Y., Han, J., Xu, J., \& Ye, X. (2017). A class of level-2 fuzzy decision-making model with expected objectives and chance constraints: Application to supply chain network design. International Journal of Information Technology \& Decision Making, 16(04), 907938. 